\title{
Qualitative evaluation and optimization of forest road network to minimize total costs and environmental impacts
}

\author{
Elyas Hayati, Baris Majnounian, Ehsan Abdi
}

An efficient and low-cost transportation network is necessary for sustainable management. Roading and log skidding are the most expensive and destructive operations in forest environment, unless carefully planned and evaluated. A transportation network has to be assessed and optimized to minimize the total cost of road construction and its environmental impact. The aim of this study was determining the optimum forest road network density, and evaluating the quantity and quality of the existing forest road network. In order to determine the optimum forest road network density, skidding cost, road construction and maintenance costs, and harvesting volume in each compartment were considered. Then optimum skidding distance was calculated with regard to optimum road density and total correction factors. The relative openness and efficiency coefficient of the existing forest road network were determined for the calculated optimum skidding distance, using ArcGIS. The results showed that the optimum road density, relative openness and road network efficiency coefficient were $21.5 \mathrm{~m} \mathrm{ha}^{-1}, 90 \%$ and $32 \%$, respectively. As a result, when the quality of a forest road network has to be evaluated, road network efficiency coefficient is more efficient than relative openness, that per se cannot be considered as an appropriate indicator.

Keywords: Forest road network, Environmental impact, Qualitative evaluation, Optimum road density, Efficiency coefficient, GIS

\begin{abstract}
Introduction
Forests support a lot of ecosystem services, including primary products, secondary products, water supply, hydrological regulation, environmental purification, soil formation, soil conservation, biodiversity conservation, recreation, etc. (Gios \& Clauser 2009, Gaodi et al. 2010). One of the main objectives of forest management is the sustainable utilization of natural resources (Mataji et al. 2010). Forest road planning plays an important role in forest management and logging practices. Roads are essential structures to provide ac-
\end{abstract}

Forestry and Forest Economics

Department, Faculty of Natural Resources, University of Tehran, Karaj, Iran

@) Elyas Hayati (hayati_fe@ut.ac.ir)

Received: Sep 23, 2011 - Accepted: Mar 19, 2012

Citation: Hayati E, Majnounian B, Abdi E, 2012. Qualitative evaluation and optimization of forest road network to minimize total costs and environmental impacts. iForest 5: 121-125 [online 2012-0605] URL:

http://www.sisef.it/iforest/contents/? id=ifor0610-009

Communicated by: Agostino Ferrara cess to the forest for wood production and logging (Abdi et al. 2009). On the other hand, road construction and log skidding are the most expensive and destructive operations in the forest environment, leading to soil compaction and increasing surface runoff and soil erosion along the skidding path. Therefore, the viability and profitability of operational forest management plans are deeply influenced by road construction and maintenance costs, as well as the road network structure (Kirby et al. 1986). A large area of forest is destroyed during road construction, provoking not only economic losses, but also changes in the environmental conditions (Jadczyk 2009). Road construction in forest may also cause biodiversity loss as a result of habitat fragmentation (Hui et al. 2003, Smulders et al. 2009, Da Silva et al. 2010), making forest communities more prone to impoverishment and depletion. As the high density of forest road network will lead to the excessive economical and environmental costs, forest road managers have to carefully evaluate and optimize the forest road network density for minimizing the total costs and environmental impacts of these infrastructures. Average log skidding distance is an important component to evaluate the quality of forest road network, and should be considered for computing the op- timal forest road network density (Zhixian \& Zhili 1997).

Matthews (1942) was the first who developed a two dimensional model for skidding distance, with assumptions of flat terrain condition, regular road distribution, and provided that logs are carried out on the shortest path to the nearest road. Segebaden (1964) improved the road spacing model by introducing network and transport correction factors. Heinimann (1997) reported that the above mentioned assumptions do not apply in mountainous conditions with sloped terrain, and introduced a slope correction factor to compute the real skidding distance.

Road technical specifications and wood extraction methods are two main factors affecting optimum road spacing and density, aimed to minimize the total cost of roading and skidding (Rowan 1976, Naghdi \& Mohammadi Limai 2009). Moreover, the timber volume to be harvested is an important factor affecting the quantity and quality of forest road network density. Sedlak (1983) calculated road spacing with regard to volume of annual growth and reported lower average road spacing in parts of forest with higher annual growth and larger harvesting volume.

There are many researches aimed to determine road and skidding costs, road spacing and generally optimal road network under different logging practices (Lihai et al. 1996, Tan 1999, Tucek \& Pacola 1999, Chung \& Sessions 2001, Heralt 2002, Demir \& Tolga 2004, Anderson \& Nelson 2004, Aruga 2005, Pentek et al. 2005, Najafi et al. 2008).

Chung \& Sessions (2001) introduced the Network 2001 program for the analysis and selection of optimum forest road network. Pentek et al. (2005) used forest road relative openness and efficiency coefficient to analysis forest road network with determination of optimum road density and average skidding distance.

In the Caspian forests, most of harvested timbers are extracted by ground-based skidding system. In that context, optimal average skidding distance must be determined as first step in order to get the optimum forest road network density. However, Caspian forests are mainly located in mountainous area, where studies based on the theoretical skidding distance (namely, those based on Matthews's model) do not apply.

The present study aimed to evaluate the quantity and quality of the existing forest road network, with estimation of optimum road density and road network efficiency coefficient in ArcGIS, with respect to road construction, maintenance and skidding cost, and harvest volume in Namkhaneh district, Kheyroud Educational and Research Forest, northern Iran. 


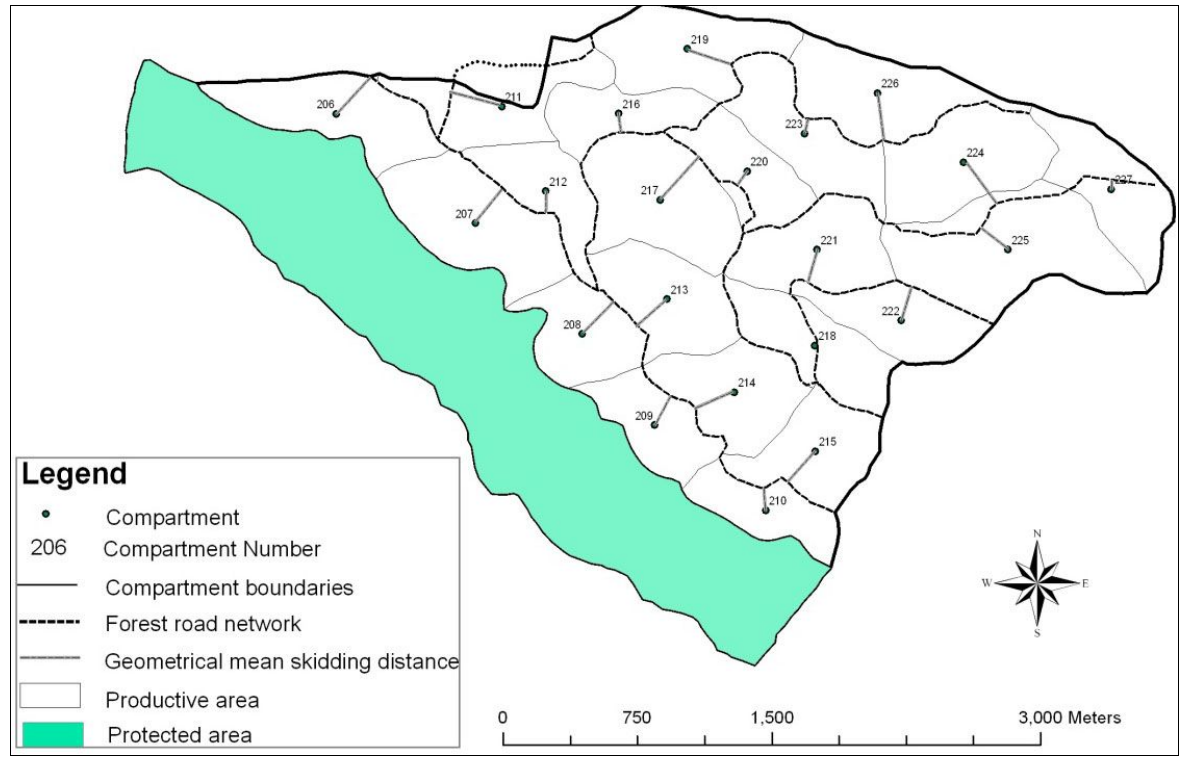

Fig. 1 - Defined geometrical mean skidding distance in each compartment.

\section{Material and methods}

Study site

The temperate deciduous forests of northern Iran, known as the Caspian forests, cover an area of around 2 million hectares, ranging from the level of the Caspian Sea up to 2200 $\mathrm{m}$ a.s.l. Oriental beech (Fagus orientalis Lipsky) is the most important broadleaved deciduous species in the Caspian region, forming natural pure and mixed forests (Ahmadi et al. 2009). The study site is located in
Nowshahr (latitude: 36³ ' N, longitude: $50^{\circ} 33^{\prime}$ E). The research was carried out on road network of Namkhaneh district, which covers $1083 \mathrm{ha}$, ranging from 350 to $1350 \mathrm{~m}$ a.s.l.; slope varies between 0 to $80 \%$. Only 788 ha of the district area are considered as harvesting area, while the rest (295 ha) were excluded as protected area. The management in the district is mixed un-even aged high forest, with single and group selective cutting regime. Forest roads are categorized as permanently main forest roads used for
Tab. 1 - Harvesting volume, $S D_{\mathrm{EG}}$ (existing geometrical mean skidding distance) and $S D_{\mathrm{ER}}$ (existing real mean skidding distance) of each compartment in the study area.

\begin{tabular}{ccccc}
\hline Compartment & $\begin{array}{c}\text { Area } \\
(\mathbf{h a})\end{array}$ & $\begin{array}{c}\text { Harvesting } \\
\text { volume } \\
\left(\mathbf{m}^{\mathbf{3}}\right)\end{array}$ & $\begin{array}{c}\boldsymbol{S D}_{\text {EG }} \\
(\mathbf{m})\end{array}$ & $\begin{array}{c}\boldsymbol{S D}_{\text {ER }} \\
(\mathbf{m})\end{array}$ \\
\hline 206 & 39.9 & 297.5 & 271.1 & 428.3 \\
207 & 49.7 & 178.5 & 233.6 & 369.1 \\
208 & 29.3 & 195.5 & 243.2 & 384.3 \\
209 & 26.2 & 246.5 & 176.7 & 279.2 \\
210 & 23.6 & 85 & 120.7 & 190.7 \\
211 & 31.1 & 238 & 284.9 & 450.1 \\
212 & 25.4 & 170 & 108.7 & 171.8 \\
213 & 35.3 & 212.5 & 209.2 & 330.5 \\
214 & 35.6 & 246.5 & 222.6 & 351.7 \\
215 & 32.2 & 221 & 219 & 346 \\
216 & 24 & 59.7 & 93 & 146.9 \\
217 & 48.6 & 238 & 308.4 & 487.3 \\
218 & 34.1 & 119.2 & 12.7 & 20.1 \\
219 & 40 & 347.8 & 245 & 387.1 \\
220 & 26.5 & 212.5 & 85 & 134.4 \\
221 & 35.6 & 297.5 & 175.2 & 276.8 \\
222 & 28.6 & 103 & 187.7 & 296.5 \\
223 & 35.2 & 246.5 & 82.1 & 129.7 \\
224 & 44 & 255 & 244.1 & 385.7 \\
225 & 66.1 & 261 & 186.8 & 295.1 \\
226 & 41.3 & 314.5 & 253 & 399.6 \\
227 & 35.3 & 212.5 & 55 & 86.6 \\
\hline
\end{tabular}

trucking, with an average width $6.5 \mathrm{~m}$ and longitudinal slope 3 to $8 \%$ (Majnounian et al. 2010). Overall raod length is $15.8 \mathrm{~km}$ and current forest road density is $20 \mathrm{~m} \mathrm{ha}^{-1}$. Ground skidding using wheeled cable skidders (Timber Jack 450C, $174 \mathrm{hp}$ and $12 \mathrm{tn}$ ) is the most common method of wood extraction in this mountainous, uneven aged hardwood forest. Cable systems are not available and not used in the Caspian forest.

Determination of the average real means skidding distance

In order to determine average real means skidding distance, the center of gravity of each compartment was defined, and its distance to the nearest road was measured in an ArcGIS environment. Indeed, this distance is the geometrical mean skidding distance for each compartment (Fig. 1), which has to be multiplied by the network correction factor to obtain the real mean skidding distance (Tab. 1). To obtain the average real means skidding distance at the district level, averages were weighted on the log volume to be harvested in each compartment.

Optimum forest road network density estimation and comparison with the existing density

The optimum forest road network density was calculated using the following equation (Rebula 1981) that consider road construction, maintenance, skidding costs and harvesting volume (eqn. 1):

$$
D_{O}=100 \cdot \sqrt{\frac{E \cdot T_{p} \cdot F \cdot K_{s}}{T_{A} \cdot T_{o}-d_{s} \cdot E}}
$$

where $D_{\mathrm{O}}$ is the optimum forest road network density $\left(\mathrm{m} \mathrm{ha}^{-1}\right), E$ is the average annual quantity of extracted $\log \left(\mathrm{m}^{3} \mathrm{ha}^{-1}\right) ; T_{\mathrm{P}}$ is the cost of skidding $1 \mathrm{~m}^{3}$ of $\log$ at the distance of $1 \mathrm{~m}\left(\mathrm{US} \$ \mathrm{~m}^{-3} \mathrm{~m}^{-1}\right) ; F$ is the walking cost factor, that Rebula (1981) estimated as $51.7 \%$ of skidding cost per skidder (see below); $K_{\mathrm{S}}$ is the overall correction factor of the theoretical mean skidding distance; $T_{\mathrm{A}}$ is the average annual amortization of $1 \mathrm{~m}$ of forest road $\left(\mathrm{US} \$ \mathrm{~m}^{-1}\right) ; T_{\mathrm{O}}$ is the average annual maintenance cost of $1 \mathrm{~m}$ of forest road $\left(\mathrm{US} \$ \mathrm{~m}^{-1}\right) ; d_{\mathrm{S}}$ is the secondary profit from the forest road network (US\$ $\mathrm{m}^{-3}$ ). Depending on the region considered, this parameter may include profits from mushrooms, resins, ornamental seeds and pods, aromatic plants or plants for pharmaceutical products, and other non-wood forest products. As wood harvesting is the main and the only profit in the study area, this parameter was not taken into account in our estimation.

To obtain the value for the walking cost factor $F$ in eqn. 1, several parameters need to be preliminarily defined, such as the number of workers, the average walking speed, the payment of workers per hour, the intensity of 
work. Considering the wheeled skidder used in the study area and the topographic conditions in this study, fairly similar to those previously reported in the literature (Rebula 1981, Pentek et al. 2005), the value of $51.7 \%$ was used.

Average optimum geometrical mean skidding distance

In order to calculate the average optimum geometrical mean skidding distance, the following equation was used (eqn. 2):

$$
S d_{O R}=\frac{K_{s}}{D_{o}} \cdot 10000
$$

where $S d_{\mathrm{OR}}$ is the average optimum real means skidding distance, $D_{\mathrm{O}}$ and $K_{\mathrm{S}}$ were already defined above.

Dividing th $S d_{\mathrm{OR}}$ by network correction factor $\left(K_{\mathrm{G}}\right)$, the average optimum geometrical mean skidding distance may be obtained (eqn. 3):

$$
S d_{O G}=\frac{S d_{O R}}{K_{G}}
$$

Determination of the forest road relative openness

Buffer zones wrapping the existing roads on both sides and extending twice the optimum average geometrical mean skidding distance were created in the ArcGIS environment (Fig. 2). Indeed, the buffer zone represents the maximum skidding distance. Then, the relative openness was calculated using the following equation (eqn. 4):

$$
O_{R} \%=\frac{O_{E}}{A_{T}} \cdot 100
$$

where $O_{\mathrm{R}}$ is the relative openness of fores road, $A_{\mathrm{T}}$ is the total area of the district (ha) and $O_{\mathrm{E}}$ is the effective opening-up area (ha) The buffer opening-up zone falling outside the district area and the overlapped buffer opening-up were excluded from this analysis.

Evaluation of the forest road network efficiency coefficient

Opening-up effectiveness indicates the effectiveness of the forest road location. In the presence of a regular road network, the effective opening-up would be at the maximum level with regard to road density. However, an ideally distributed road network does not occur in practice (Hruza 2003). In order to calculate the forest road network efficiency coefficient, the following equation was used (eqn. 5)

$$
K_{U} \%=\left[1-\frac{O_{I}}{O_{E}}\right] \cdot 100
$$

where $K_{\mathrm{U}}$ is the efficiency coefficient of forest road network, $O_{\mathrm{E}}$ is the effective opening-up area (ha), and $O_{\mathrm{I}}$ is the ineffective

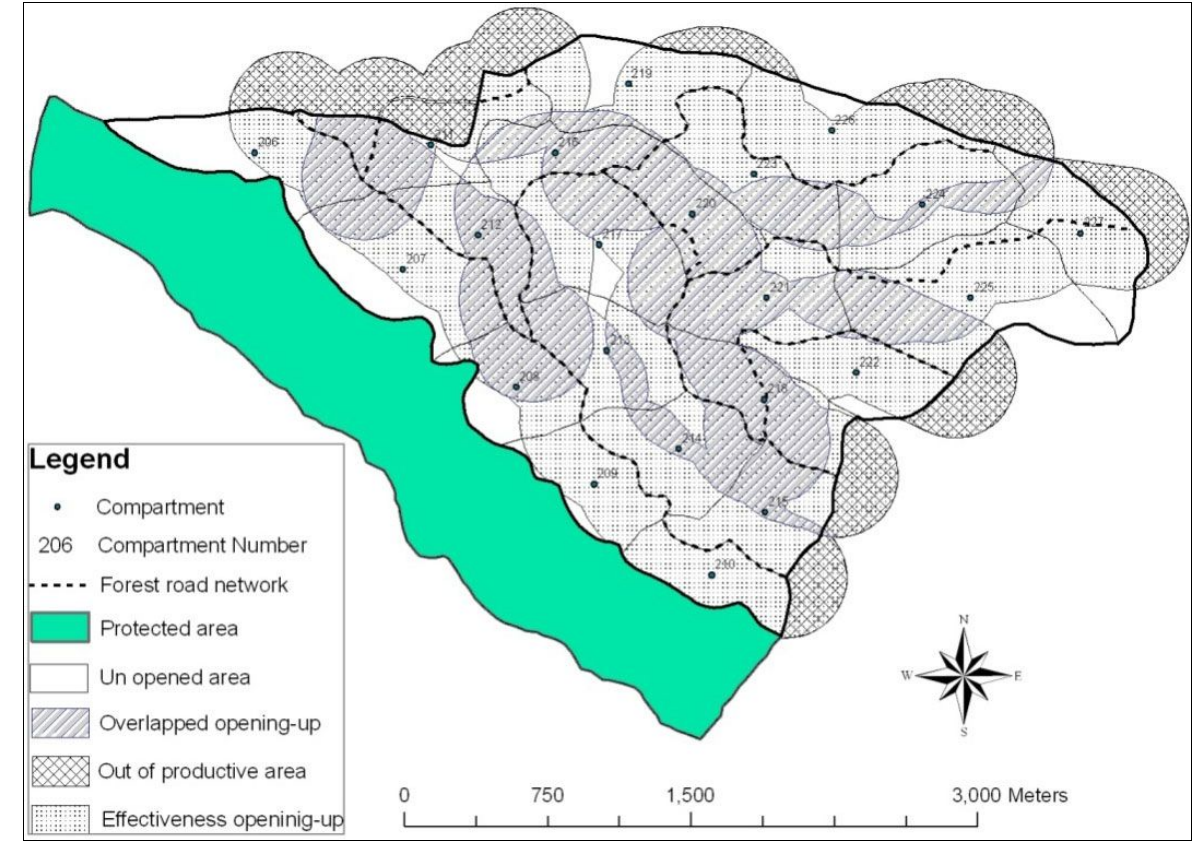

Fig. 2 - Effective opening-up and dead zone areas. opening-up area, i.e., the overlapped buffer opening-up and the part of buffers falling outside the district area (ha).

\section{Results}

Average existing real mean skidding distance

To calculate the existing real mean skidding distance, the existing geometrical mean skidding distance in each compartment was multiplied by the correction factor $\left(K_{\mathrm{G}}\right)$ of 1.58 , as reported by Pentek et al. (2005). The average existing real mean skidding distance $\left(S d_{\mathrm{ER}}\right)$ at district level was estimated taking into account the harvesting volume $(E)$ and existing real mean skidding distance $\left(S d_{\mathrm{ER}}\right)$ in each compartment (Tab. 1), obtaining a value of $310 \mathrm{~m}$ (eqn. 6):

$$
\overline{S d}_{E R}=\frac{\sum_{i=1}^{n} S d_{E R(i)} \cdot E_{i}}{\sum_{i=1}^{n} E_{i}}=310 \mathrm{~m}
$$

\section{Optimum road network density}

The forestry center of the Kheyroud Educational and Research Forest has defined and reported the costs of road construction and maintenance. To have a set of comparable costs - as different road sections have been constructed in different times -, the cost of each section was actualized to a certain year, using the average interest rate of the Iran Central Bank. According to the above forestry center report, the annual road construction cost and road maintenance cost were estimated $52.5 \mathrm{US}^{-1}$ year $^{-1}$ and 1.1 US\$ $\mathrm{m}^{-1}$ year-1, respectively. Value of the annual road amortization cost over a period of

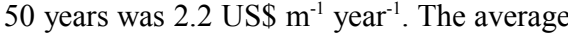
harvesting volume calculated using weighted averages was $6.2 \mathrm{~m}^{3} \mathrm{~h}^{-1}$. Skidding operations in the study area is carried out by a contractor company, whose costs are $25 \mathrm{US} \$ \mathrm{~m}^{-3}$, with no variable or fixed skidding cost. Considering the skidding cost $\left(25 \mathrm{US}^{-3}\right)$ and distance $(310 \mathrm{~m})$, the parameter $F$ takes the value of 0.042 (eqn. 7 ):

$$
F=\frac{25}{310} \cdot 0.517=0.042
$$

Majnounian et al. (2009) reports values for the total correction factor $\left(K_{\mathrm{S}}\right)$ for Kheyroud Forest from 2 (gentle slope) to 2.63 (steep terrain). We used $K_{\mathrm{S}}=2.3$, because Namkhaneh district area extends over low and steep terrain (mean slope angle 35\%) and due to the both sides skidding, a value of 0.575 was used in the eqn. 1 . Finally, the optimum road density value obtained $\left(D_{\mathrm{O}}\right)$ was $21.5 \mathrm{~m} \mathrm{ha}^{-1}$.
Tab. 2 - $O_{\mathrm{R}}$ and $K_{\mathrm{U}}$ of existing forest road network. $\left(O_{\mathrm{T}}\right)$ : total opening-up area; $\left(O_{\mathrm{D}}\right)$ : double opening-up area; $\left(O_{\mathrm{O}}\right)$ : outer opening-up area; $\left(O_{\mathrm{I}}\right)$ : ineffective opening-up area; $\left(O_{\mathrm{E}}\right)$ : effective opening-up area; $\left(O_{\mathrm{R}}\right)$ : relative openness; $\left(K_{\mathrm{U}}\right)$ : efficiency coefficient.

\begin{tabular}{cccccccc}
\hline $\begin{array}{c}\text { Harvesting area } \\
\text { (ha) }\end{array}$ & $\begin{array}{c}\mathbf{O}_{\mathbf{T}} \\
\text { (ha) }\end{array}$ & $\begin{array}{c}\mathbf{O}_{\mathbf{D}} \\
\text { (ha) }\end{array}$ & $\begin{array}{c}\mathbf{O}_{\mathbf{o}} \\
\text { (ha) }\end{array}$ & $\begin{array}{c}\mathbf{O}_{\mathbf{I}} \\
\text { (ha) }\end{array}$ & $\begin{array}{c}\mathbf{O}_{\mathbf{E}} \\
\text { (ha) }\end{array}$ & $\begin{array}{c}\mathbf{O}_{\mathbf{R}} \\
\mathbf{\%}\end{array}$ & $\begin{array}{c}\mathbf{K}_{\mathbf{U}} \\
\text { \% }\end{array}$ \\
\hline 788 & 1192 & 328 & 154 & 482 & 710 & 90 & 32 \\
\hline
\end{tabular}


Average optimum geometrical mean skidding distance

Considering, $D_{\mathrm{O}}=21.5 \mathrm{~m} \mathrm{ha}^{-1}$ and $K_{\mathrm{S}}=$ 0.575 , the average optimum real mean skidding distance was $267 \mathrm{~m}$ (eqn. 8):

$$
S d_{O R}=\frac{0.575}{21.5} \cdot 10000=267 \mathrm{~m}
$$

As the buffers are formed on the road network layout using the geometrical skidding distance, the average optimum geometrical mean skidding distance $\left(S d_{\mathrm{OG}}\right)$ was calculated using $K_{\mathrm{G}}=1.58$ (eqn. 9):

$$
S d_{O G}=\frac{267}{1.58}=168 \mathrm{~m}
$$

\section{Relative openness}

The relative openness was calculated dividing effective opening-up by the total district area (Tab. 2 - eqn. 10):

$$
O_{R} \%=\frac{710 \mathrm{ha}}{788 \mathrm{ha}} \cdot 100=90 \%
$$

\section{Efficiency coefficient of the forest road network}

Effective opening-up was 710 ha and ineffective opening-up (the area of buffers either overlapping or falling outside the district area) was 482 ha. Therefore, the forest road network efficiency coefficient obtained was $32 \%$ (Tab. 2 - eqn. 11):

$$
K_{U} \%=\left[1-\frac{482 \mathrm{ha}}{710 \mathrm{ha}}\right]=32
$$

\section{Discussion}

The popular method by Matthews (1942), commonly used to assess a forest road network efficiency, is unsuitable for Caspian forests because its assumptions do not hold in the context analyzed. In this study, to calculate the real skidding distance and optimum road network density, two correction factors were considered. The current road density was $20 \mathrm{~m} \mathrm{ha}^{-1}$ and the current average mean skidding distance using the center of gravity method was $310 \mathrm{~m}$. The obtained value for optimal road density $\left(21.5 \mathrm{~m} \mathrm{ha}^{-1}\right)$ considering road construction and maintenance costs, skidding cost and the harvesting volume, was a slightly higher than the actual road density. According to the Iranian Plan and Budget Organization (IPBO), a value of $20 \mathrm{~m} \mathrm{ha}^{-1}$ is considered as the optimum road density for the current logging and transportation system in the Caspian forests (IPBO 2000). Moreover, Lotfalian (2002), considering a ground skidding system (Timber Jack 450C) and different characters (i.e., slope, skidding cost, correction factors, soil type, etc.) in the Sangdeh forest (northern Iran), reported an optimum forest road density $\left(21 \mathrm{~m} \mathrm{ha}^{-1}\right)$ comparable with the results of this study. Therefore, the value $21.5 \mathrm{~m}$ $\mathrm{ha}^{-1}$ can be suggested as an optimal and economical density for road network in the Caspian forests, as well as in regions with terrain conditions, logging and wood extracting methods similar to our study area.

Optimal average mean skidding distance, relative openness and efficiency coefficient of the studied forest road network were 267 $\mathrm{m}, 90 \%$ (excellent openness) and 32\%, respectively. Based on the results obtained, the actual road density in the area $\left(20 \mathrm{~m} \mathrm{ha}^{-1}\right)$ is roughly adequate. However, the low value of the efficiency coefficient (32\%) suggests that the studied road network do not present a proper distribution. In other words, road networks with a low efficiency coefficient may lead to habitat and biodiversity losses in the future, due to forest fragmentation into smaller and more isolated patches as a consequence of sub-optimal harvesting practices (Chomitz \& Gray 1996, Forman et al. 1997, Geneletti 2003, Hui et al. 2003). Based on the relative openness only, the forest road network seems to show a well opening-up and function. On the other hand, the road network efficiency coefficient obtained indicates a fairly high level of ineffective opening-up. Therefore, it can be concluded that road network efficiency is lower than the value that of relative openness indicated. Analogously, Pentek et al. (2005) reported the relative openness $(81.4 \%)$ and the efficiency coefficient $(42.37 \%)$ of a forest road network in Croatia.

In the Caspian forest, the relative openness is commonly used as a suitable indicator for the selection of the best road network variants (e.g., Goudarzi 1999, Sepahvand 2004, Puya et al. 2009). Nonetheless, in this investigation, despite a very good relative openness $(90 \%)$, the efficiency coefficient of the studied road networks were not satisfactory $(32 \%$ only). It may thus be suggested that the road network efficiency coefficient, that considered the ratio of ineffective to effective opening-up, is a more reliable indicator of the forest road network quality and efficiency.

\section{Conclusion}

Forest road network plays an important role in sustainable forest management, which has to be planned as much optimally as possible. To achieve an optimal road network with low-costs and high-quality, the following points are recommended:

- taking into account all the economical parameters such as the skidding costs, road construction and maintenance costs for the road network optimization;

- taking into account the harvesting volume and the possible secondary forest products, because they can also increase road network density;

- considering the efficiency coefficient to analyze the quality of the forest road net- work variants, as showed in this study, it is a more precise indicator for the qualitative evaluation and optimization of a forest road network;

- considering other functions of forest roads like ecotourism, forest fire extinction, etc, in forest road network assessment.

\section{Acknowledgments}

The authors wish to thank Eng. J. Fathi, manager of the Kheyroud Educational and Research Forest, University of Tehran, for his helpful assistance in data and maps supply. We also would like to express our thanks to Dr. I. Potočnik, University of Ljubljana, Biotechnical Faculty, for his kind collaboration. This work was financed by University of Tehran. The authors also express their appreciation to two anonymous reviewers for their helpful and valuable comments and suggestions.

\section{References}

Abdi E, Majnounian B, Darvishsefat A, Mashayekhi Z, Sessions J (2009). A GIS-MCE based model for forest road planning. Journal of Forest Science 55 (4): 171-176. [online] URL: http://www.agriculturejournals.cz/publicFiles/05 121.pdf

Ahmadi MT, Attarod P, Marvi Mohadjer MR, Rahmani R, Fathi J (2009). Partitioning rainfall into throughfall, stemfow, and interception loss in an oriental beech (Fagus orientalis Lipsky) forest during the growing season. Turkish Journal of Agriculture and Forestry 33: 557-568.

Anderson AE, Nelson J (2004). Projecting vectorbased road networks with shortest path algorithm. Canadian Journal of Forest Research 34 (7): 1444-1457. - doi: 10.1139/x04-030

Aruga K (2005). Tabu search optimization of horizontal and vertical alignments of forest roads. Journal of Forest Research 10: 275-284. - doi: 10.1007/s10310-004-0136-5

Chomitz KM, Gray DA (1996). Roads, land use, and deforestation: a spatial model applied to Belize. World Bank Econ. Rev. 10: 487-512. - doi: 10.1093/wber/10.3.487

Chung W, Sessions J (2001). NETWORK 2001 Transportation planning under multiple objectives. In: "The International Mountain Logging" and " $11^{\text {th }}$ Pacific Northwest Skyline Symposium".

Da Silva AM, Braga Alves C, Alves SH (2010). Roadside vegetation: estimation and potential for carbon sequestration. iForest 3: 124-129. - doi: 10.3832/ifor0550-003

Demir M, Tolga O (2004). A research on forest road planning and projecting by inroads software in Bolu region of Turkey. American Journal of Applied Science 1 (4): 295-301. - doi: 10.3844/ ajassp.2004.295.301

Forman RTT, Friedman DS, Fitzhenry D, Martin JD, Chen AS, Alexander LE (1997). Ecological effects of roads: toward three summary indices and an overview for North America, pp. 40-54. Gaodi X, Wenhua L, Yu X, Biao Z, Chunxia L, 
Kai A, Jixing W, Kang X, Jinzeng W (2010). Forest ecosystem services and their values in Beijing. Chinese Geographical Science 20 (1) 51-58. - doi: 10.1007/s11769-010-0051-y

Geneletti D (2003). Biodiversity impact assessment of roads: an approach based on ecosystem rarity. Environmental Impact Assessment Review 23: 343-365. - doi: 10.1016/S0195-9255 (02)00099-9

Gios G, Clauser O (2009). Forest and tourism: economic evaluation and management features under sustainable multifunctionality. iForest 2: 192-197. - doi: 10.3832/ifor0514-002

Goudarzi M (1999). Study of variants for completing of forest road network in Namkhaneh district. M. Sc. thesis, Faculty of Natural Resources, Tehran University, pp. 110. [in Persian with English abstract].

Heinimann HR (1997). A computer model to differentiate skidder and cable-yarder based road network concepts on steep slopes. Journal of Forest Research 3: 1-9. - doi: 10.1007/BF0276 0286

Heralt L (2002). Using the ROADENG system to design an optimum forest road variant aimed at the minimization of negative impacts on the natural environment. Journal of Forest Science 48 (8): 361-365.

Hruza P (2003). Optimization of forest road network under principles of functionally integrated forest management. Journal of Forest Science 49 (9): 439-443.

Hui C, Shuang-cheng L, Yi-li Z (2003). Impact of road construction on vegetation alongside Qinghal-Xizang highway and railway. Chinese Geographical Science 13 (4): 340-346. - doi: 10.1007/s11769-003-0040-5

IPBO (2000). Guidelines for design, execute and using forest roads $\left(2^{\text {nd }}\right.$ ed.). No. 131 , Office of the Deputy for Technical Affairs, Bureau of Technical Affairs and Standards, Iranian Plan and Budget Organization, pp. 170. [in Persian]

Jadczyk P (2009). Natural effects of large-area forest decline in the western Sudeten. Environment Protection Engineering 35 (1): 49-56. [on- line] URL: http://epe.pwr.wroc.pl/2009/Jadczyk_ 1-2009.pdf

Kirby M, Hager W, Wong W (1986). Simultaneous planning of woodland management and transportation alternatives. TIMS Studies in the Management Sciences 21: 371-387.

Lihai W, Fulong M, Chunshan L, Zhongye G, Jianfeng S (1996). Assessment of animal skidding and ground machine skidding under mountain conditions. Journal of Forestry Research 7 (1): 63-72. - doi: 10.1007/BF02843060

Lotfalian M (2002). Study in effective characters for determining optimal density of forest road network. Ph.D. dissertation, College of Natural Resource, University of Tehran, Iran, pp. 130. [in Persian]

Majnounian B, Chegeni M, Sobhani H, Abdi E (2009). Determination of correction factor for skidding distance in mountainous forests of Northern Iran. Journal of Forest and Wood Products 62 (3): 313-323. [in Persian with English summary]

Majnounian B, Abdi E, Zobeiri M, Puya K (2010). Monitoring the conditions of forest road network compared to the standards (Case study: Namkhaneh District of Kheyrood Forest). Journal of Forest and Wood Products 63 (2): 177186. [in Persian with English summary]

Mataji A, Moarefvand P, Babaie Kafaki S, Madanipour Kermanshahi M (2010). Understory vegetation as environmental factors indicator in forest ecosystems. International Journal of Environmental Science and Technology 7 (4): 629638.

Matthews DM (1942). Cost control in the logging industry. McGraw-Hill, New York, USA, pp. 374.

Naghdi R, Mohammadi Limai S (2009). Optimal forest road density based on skidding and road construction cost in Iranian Caspian Forest. Caspian Journal of Environmental Science 7 (2): 79-86.

Najafi A, Sobhani H, Saeed A, Makhdom M, Mohajer MM (2008). Planning and assessment of alternative forest road and skidding networks.
Croatian Journal of Forest Engineering 29 (1): 63-73.

Pentek T, Picman D, Potocnic I, Dvorscak P, Nevecerel H (2005). Analysis of an existing forest road network. Croatian Journal of Forest Engineering 26 (1): 39-50.

Puya K, Majnounian B, Feghhi J, Lotfalian M, Abdi E (2009). The efficiency of Backmund method for the evaluation of forest road networks with regard to capabilities of wheeled skidders in ground skidding method. Iranian Journal of Forest 1 (1): 35-42. [in Persian with English summary]

Rebula E (1981). Optimal openness of forests. Mehanizacija šumarstva 3-4 (5): 107-119.

Rowan A (1976). Forest road planning. Forestry commission booklet 43, pp. 29

Sedlak O (1983). General principals of planning forest road nets. FAO 14 (1): 17-36.

Segebaden GV (1964). Studies of cross-country transport distance and road net extension. Studia forestalia suecica 18: 70 .

Sepahvand A (2004). Studying different road network variants opening ability to complete road network of Patom district in a multi-purpose forest management. M.Sc. thesis, College of Natural Resource, University of Tehran, Iran, pp. 142. [in Persian with English summary]

Smulders MJM, Cobben MMP, Arens P, Verboom J (2009). Landscape genetics of fragmented forests: anticipating climate change by facilitating migration. iForest 2: 128-132. - doi: 10.3832/ifor0505-002

Tan J (1999). Locating forest roads by a spatial and heuristic procedure using microcomputers. Journal of Forest Engineering 10 (2): 91-100. [online] URL: http://journals.hil.unb.ca/index .php/IJFE/article/view/9964/10196

Tucek J, Pacola E (1999). Algorithms for skidding distance modeling on a raster digital terrain model. Journal of Forest Engineering 10 (1): 67-79. Zhixian Z, Zhili F (1997). The method of calculating average skidding distance. Journal of Forestry Research 8 (1): 47-49. - doi: 10.1007/ BF02864941 